\title{
Nesting habitat selection by sage grouse in south- central Washington
}

\author{
COLIN M. SVEUM, W. DANIEL EDGE, AND JOHN A. CRAWFORD
}

Authors are biological sciences technician, U.S. Geological Survey, Upper Mississippi Science Center, 2630 Fanta Reed Road, La Crosse, Wisc. 54603; associute professor, Department of Fisheries und Wildife, Oregon State University, Nash 104, Corvallis, Ore. 97331-3803; and professor, Department of Fisheries and Wildlife, Oregon State University, Nash 104, Corvallis, Ore. 97331-3803. At the time of the research, the senior author was graduate research assistant, Department of Fisheries and Wildlife, Oregon State University, Corvallis, Ore.

\author{
Abstract
}

To characterize western sage grouse (Centrocercus urophasianus phaios Bonaparte) nesting habitat in sagebrush-steppe babitat in Washington, we initiated a study on the Yakima Training Center to determine nesting habitat characteristics and whether these characteristics differed between successful and depredated nests. Most nests (71\%) were in big sagebrush (Artemesia tridentata Nutt)/bunchgrass communities. Nest habitat was characterized by greater shrub cover, shrub height, vertical cover height, residual cover, and litter than at random locations. Successful $1-\mathrm{m}^{2}$ nest sites within big sagebrush/bunchgrass in 1992 had less shrub cover $(51 \%)$ and shrub height $(64 \mathrm{~cm})$ than depredated nest sites $(70 \%$ and $90 \mathrm{~cm}$, respectively). Successful $77-\mathrm{m}^{2}$ nest areas in big sagebrush/bunchgrass in 1993 had more tall grass $(\geq 18 \mathrm{~cm}$ ) than depredated nest areas. Management that protects the big sagebrush/bunchgrass community is essential for maintaining nesting habitat for sage grouse.

Key Words: Centrocercus urophasianus, predation, reproduction

A $40 \%$ loss of shrub-steppe and meadow steppe habitat since European settlement, combined with habitat alteration, has nearly eliminated sage grouse from Washington (Wash. Dept. Fish and Wildl. 1995). The Yakima Training Center (YTC), a military training ground, contains the largest block of remaining sage grouse habitat in Washington.

The importance of sagebrush (Artemesia spp.) cover for nesting sage grouse is well documented (Wallestad and Pyrah 1974, Connelly et al. 1991). Recent studies have focused on the importance of herbaceous cover as a key component intluencing nest fate of sage grouse. Wakkinen (1990) suggested that grass cover and height may be important factors in sage grouse nestsite selection and fate in southeastern Idaho. In southeastern

\footnotetext{
This study was funded by Pacific Northwest Laboratory under a contract with the U.S. Department of Defense (DOD). J. Klabon, T. Kollasch, M. Lacroix, A Leary, and K. Hand assisted with data collection. We thank L. Cadwell and L. E. Eberhardt for their logistical support and liaisons with DOD. D. Pyke provided valuable comments on the manuscript. Publication of this paper was supported, in part, by the Thomas G. Scott Publication Fund. This is manuscript 11,089 of the Oregon Agricultural Experiment Station.

Manuscript accepted 30 July 1997.
}

\section{Resumen}

Para caracterizar el hábitat donde el urogallo de artemisa del oeste (Centrocercus urophasianus phaios Bonaparte) construye su nido, el cual está en un hábitat de artemisa en Washington, iniciamos un estudio en el centro de entrenamiento en Yakima para determinar las características de anidar y si estas difiere entre los nidos que tienen éxito y los que han sido depredados. La mayoria de los nidos $(71 \%)$ estaban en la gran artemisa (Artemesia tridentata Nutt.) o en regiones de mata de hierba. El hábitat del nido se caracteriza por estar mayormente en zonas de arbustos de cobertura, arbustos altos, arbustos que cubren verticalmente, arbustos de cubierto residual y más basura que sitios que fueron escogidos al azar. Los nidos con éxito $1-\mathrm{m}^{2}$ dentro de la gran artemisa o mata de hierbas, en 1992, estaban en lugares con arbustos de menos cobertura (51\%) y con arbustos de menos altura $(64 \mathrm{~cm})$ que los sitios de nidos depredados $(70 \%$ y $90 \mathrm{~cm}$, respectivamente). Las áreas de nidos con éxito $77-\mathrm{m}^{2}$ en la gran artemisa o mata de hierbas en 1993 tenían más hierba alta $\geq 18$ cm) que las áreas de nidos depredados. Una política de protección de la gran artemisa o zonas de mata hierba es esencial para mantener el hábitat para el urogallo de artemisa.

Oregon, successful sage grouse nests had greater cover of tall grasses $(>18 \mathrm{~cm})$ and medium-height shrubs $(40-80 \mathrm{~cm})$ than unsuccessful nests (Gregg et al. 1994). On the same study area, Delong et al. (1995) found that artificial nests in medium-height shrub cover $(40-80 \mathrm{~cm})$ and $>10 \%$ grass cover were depredated less than nests in medium-height shrub cover and $\leq 10 \%$ grass cover.

Limited sage grouse nesting information is available for Washington (Hofmann 1991) and is needed because the species is a Category 2 species for listing under the Endangered Species Act, and currently occurs in only 2 populations in Washington. Our objectives were to determine use and selection of cover types and determine the structure and composition of specific habitat components within cover types used by nesting sage grouse on the YTC. We tested the null hypotheses of no differential use of cover types by nesting hens and no differences in habitat components at nests and random locations, and between successful and depredated nests. 


\section{Study Area}

We conducted this study in 1992 and 1993 on the Yakima Training Center (YTC) (Longitude $120^{\circ} 20^{\prime}$ Latitude 46 40'), a $1,058-\mathrm{km}^{2}$ area in Yakima and Kittitas counties, $12 \mathrm{~km}$ northeast of Yakima, Washington. The YTC is bordered by the Saddle Mountains to the north, Yakima Ridge to the south, the Columbia River to the east, and Interstate Highway 82 to the west. Elevations range from 183 to $1,249 \mathrm{~m}$.

The climate of the YTC is characterized by hot, dry summers and cool, dry winters. Long-term (1962-1991) growing season (Sep.-Aug.) precipitation averaged $20.4 \mathrm{~cm}$ (U.S. Department of Commerce Climatological Database, Yakima Air Terminal). Total growing season precipitation in 1991-92 and 1992-93 was 16.7 and $22.5 \mathrm{~cm}$, respectively. Precipitation during the 5 growing seasons before $1992-93$ was $7-25 \%$ below the long-term mean. Weather on the YTC during the winter of 1992-93 was characterized by heavy snowfall and cool temperatures. Below normal temperatures and above normal precipitation beginning during winter 1992-93 lasted into the summer of 1993.

Military training intensity in 1992 and 1993 was 288,765 and 231,302 person-days, respectively. Approximately $5 \%$ of the YTC is covered by trails due to frequent off-road use during military training (Joachim Stephan, Pac. Northwest Lab., pers. commun.). This disturbance increased erosion and facilitated establishment of knapweed (Centaurea spp.) and cheatgrass (Bromus tectorum L.). The YTC was grazed by livestock at rates of 0.13 and 0.15 AUM/ha, during 1992 and 1993, respectively.

We identified 5 cover types on the YTC using LANDSAT and SPOT satellite imagery. A big sagebrush (A. tridentata)/bunchgrass cover type ( $46 \%$ of study area) occurred on level and rolling topography at low to mid elevations, and was characterized by big sagebrush, three-tipped sagebrush ( $A$. tripartita Rydb.), green rabbitbrush (Chrysothamnus viscidiflorus [Hook] Nutt.), gray rabbitbrush ( $C$. nauseosus Pall.), bluebunch wheatgrass (Agropyron spicatum [Rydb.] Scribn.), Sandberg's bluegrass (Poa sandbergii Vasey), and bottlebrush squirreltail (Sitanian hystrix Nutt.). A grassland cover type (34\% of study area) occurred on sagebrush sites that had been burned, removing the sagebrush component. Green and gray rabbitbrush were common in this cover type, and the grass component was similar to the big sagebrush/bunchgrass type. A stiff sagebrush (A. rigida Nutt.)/bluegrass cover type (11\% of study area) was found on rocky soils on ridgetops and was composed primarily of stiff sagebrush and Sandberg's bluegrass. The altered big sagebrush/bunchgrass cover type (8\% of study area) was similar to the big sagebrush/bunchgrass type except that it contained high levels of bare ground and reduced shrub cover and structure because of military training activities. The riparian cover type (1\% of study area) occurred along ephemeral streams and other wet areas and was characterized by willow (Salix spp.), currant (Ribes spp.), hawthorn (Cratageus spp.), Baltic nush (Juncus balticus Willd.), sedge (Carex spp.) and giant wild rye (Elymus cinereus Scribn. and Merr.). Plant nomenclature follows Hitchcock and Cronquist (1987).

\section{Methods}

We captured sage grouse hens by spotlighting and with walk-in traps (Giesen et al. 1982, Schroeder and Braun 1991) during
March 1992 and 1993. Each hen was fitted with a radio transmitter, which weighed $<2 \%$ of hen mass, and a numbered aluminum leg band. We used poncho and necklace attachments in 1992 and 1993, respectively.

We located radio-collared hens weekly during the nesting season, and used caution not to disturb hens during relocations. Each location was determined with a global positioning system (GPS) in Universal Transverse Mercator (UTM) coordinates.

Nest fate was determined by condition of eggshell membranes or, in 3 instances ( 2 in 1992, 1 in 1993), observations of a hen with young. A nest was successful if $\geq 1$ egg hatched. We classified nests containing eggshell fragments with firmly attached shell membranes or missing eggs as unsuccessful. Nests abandoned because of our activities ( 3 in 1992, 1 in 1993) were used in 3rd-order selection analyses but were not included in nest success estimates or 4th order analyses.

We followed the hierarchical structure of resource selection developed by Johnson (1980) and examined 3rd order (selection of cover types) and 4th-order (selection of habitat components within cover types) habitat selection by nesting sage grouse. Availability of cover types (3rd-order) for nesting was determined within a composite minimum convex polygon home range (Odum and Kuenzler 1955) with a Geographic Information System. The composite home range was based on radio locations collected from all nesting sage grouse from March through June. Availability for 4 th-order selection was determined by measuring randomly generated UTM coordinates (located with a hand-held GPS) from the composite home range each nesting season. Only the cover types most often used for nesting (big sagebrush/bunchgrass, grassland, and altered big sagebrush/bunchgrass) were sampled for 4 th order availability data during each nesting season. We measured successful nests after hatch dates, depredated nests on estimated hatch dates, and random locations during May through June.

Vegetation measured within a $1-\mathrm{m}^{2}$ plot at each nest or random UTM coordinate was defined as the nest site, whereas vegetation surrounding the $1-\mathrm{m}^{2}$ plot was defined as the nest area. For area measurements, we centered 2 perpendicular $10-\mathrm{m}$ transects at each nest or random location; the direction of the first transect was determined randomly. We estimated canopy coverage of all shrubs along each transect by the line intercept technique (Canfield 1941). Cover of grasses, forbs, litter, standing dead cover, and bare ground along the transects was estimated within ten $0.1-\mathrm{m}^{2}$ plots (Daubenmire 1959). Residual cover was defined as any upright dead vegetation and consisted primarily of Russian thistle (Salsola kali L.), sagebrush, knapweed, and tumble mustard (Sisymbrium altissimum [L.] Britt.). We measured maximum height $(\mathrm{cm})$ for shrubs and residual cover based on the tallest plant along each transect, and estimated mean droop height (excluding flowering parts) for grasses. We classificd grass height as short $(<18 \mathrm{~cm})$ or tall $(\geq 18 \mathrm{~cm})$. Shrub cover in $1-\mathrm{m}^{2}$ plots was visually estimated. To avoid overlap in shrub cover estimates between sites and areas, line intercept measurements along the central $2 \mathrm{~m}$ were not included in each area transect. We measured vertical cover height at nest bowls or random sites with a modified Robel pole (Robel et al. 1970) and recorded vertical cover height from 4 readings (2 each along the 2 perpendicular 10 -m transects) taken $4 \mathrm{~m}$ from the pole and at $1 \mathrm{~m}$ height.

We used Fisher's exact test to test the null hypothesis that success of initial nests was the same in big sagebrush/bunchgrass as in remaining cover types combined. We used a Z-test with a con- 
tinuity correction (Zar 1984:395-397) to test the null hypothesis that nest success was the same for nests under sagebrush and nonsagebrush cover within years. For 3 rd-order analysis, we tested the null hypothesis of no differential use of cover type by comparison of cover-type use by radio-collared nesting hens (observed) to the availability of each cover type (expected) by Chi-square analysis. Only first nest attempts were used for this analysis. If we detected a significant difference between use and availability, Bonferroni simultaneous confidence intervals were calculated to determine which cover types were used disproportionately (Neu et al. 1974).

We used 4th-order data to develop a Multivariate Analysis of Variance (MANOVA) model for each spatial level (sites and areas) to test annual variation. Each model had 2 main effects, year $(1992,1993)$ and location (nest, random), and an interaction term (year $\times$ location). We used 1st nest and renest locations for 4th-order analyses. The null hypotheses for 4 th-order analyses were (1) vegetation characteristics of nest and random locations did not differ, and (2) vegetation characteristics of successful nests were not different from depredated nests. Significant year differences were detected in preliminary tests in forb cover, short grass, and litter in both the nest site and nest area 4th-order MANOVA models, so we analyzed nest data by year with analysis of variance (ANOVA) for unbalanced data and protected least significant difference mean separation tests (Proc. GLM, SAS Inst. 1989). Vegetation variables with nonnormal distributions were transformed (logit transformation for proportional data and $\log$ transformation for height data). However, we report nontransformed means and standard errors. All statistical tests were 2tailed and considered significant at $\alpha=0.10$.

\section{Results}

We fitted 45 and 40 sage grouse hens with radio transmitters during the first 3 weeks of March in 1992 and 1993, respectively. Nest success, including renesting, was $31 \%$ (11 of 35) in 1992 and $47 \%$ (27 of 58 ) in 1993. Eight of 29 hens (28\%) and 11 of 47 hens (23\%) renested in 1992 and 1993, respectively. We determined sage grouse cover type selection from 27 and 45 first nest attempts in 1992 and 1993, respectively. We also measured 90 random locations during the 2 nesting seasons (60 in 1992, 30 in 1993).

The majority of first nest attempts each year were found in big sagebrush/bunchgrass (56\% in 1992, 70\% in 1993). During 1993 , sage grouse nested in big sagebrush/bunchgrass more than expected. Each year, sage grouse nested in stiff sagebrush/bluegrass and grassland cover types less than expected; both altered big sagebrush/bunchgrass and riparian cover types were used in proportion to availability.

In 1992, 36\% (5 of 14) of first nests in big sagebrush/bunchgrass were successful, but only $9 \%$ ( 1 of 11 ) of all first nests in remaining cover types were successful ( $P=0.18$, Fisher's exact test). In $1993,45 \%$ (14 of 31 ) of first nests in big sagebrush/bunchgrass were successful, whereas nests in the remaining 3 cover types were successful $46 \%$ ( 6 of 13) of the time ( $P=0.99$, Fisher's exact test)

In $1992,71 \%$ of sage grouse nests were under big sagebrush, and $29 \%$ under residual and nonshrub cover. In 1993, 66\% of nests were under big sagebrush, $8 \%$ under three-tipped sagebrush, and $26 \%$ under residual and nonshrub cover. Nest success under sagebrush was not different from success under nonsagebrush cover in 1992 (36\% sagebrush, 10\% nonsagebrush, $Z=$ $1.11, \mathrm{P}=0.27$ ) or 1993 (45\% sagebrush, $42 \%$ nonsagebrush, $\mathrm{Z}=$ $-0.09, P=0.57$ ).

Sage grouse nest sites and nest areas had greater shrub cover, shrub height, and litter than present at random locations (Table 1). Nest sites had greater vertical cover height each year and greater standing dead cover than random sites in 1992. Each year random sites had greater short grass cover and bare ground than nest sites, whereas random nest areas had greater short grass cover in 1992 and greater bare ground in 1993.

Only big sagebrush/bunchgrass had a sufficient sample size for within cover-type analysis each year (21 nests in 1992, 45 nests in 1993). Nest sites in big sagebrush/bunchgrass each year had greater shrub cover, shrub height, vertical cover height, and litter. and less bare ground, compared with random big sagebrush/bunchgrass sites $(P<0.01)$. Nest areas in 1992 had greater shrub cover and height than random areas $(P<0.01)$. Nest sites had less short grass cover than random sites in 1992 and 1993 ( $\mathrm{P} \leq 0.02)$.

Successful nest sites and nest areas in 1992 had greater residual cover and height than depredated nests (Table 2). Successful

Table 1. Mean (SE) habitat characteristics of sage grouse nest vs random sites, and nest vs random areas on the Yakima Training Center, Yakima and Kittitas counties, Washington, 1992-93.

\begin{tabular}{|c|c|c|c|c|c|c|c|c|c|c|c|c|}
\hline \multirow[b]{3}{*}{ Variable } & \multicolumn{6}{|c|}{ Nest Sites } & \multicolumn{6}{|c|}{ Nest Areas } \\
\hline & \multicolumn{3}{|c|}{1992} & \multicolumn{3}{|c|}{1993} & \multicolumn{3}{|c|}{1992} & \multicolumn{3}{|c|}{1993} \\
\hline & $\begin{array}{c}\text { Nest } \\
(\mathrm{n}=35)\end{array}$ & $\begin{array}{l}\text { Random } \\
(n=60)\end{array}$ & $\mathbf{P}^{\mathbf{a}}$ & $\begin{array}{c}\text { Nest } \\
(\mathrm{n}=58)\end{array}$ & $\begin{array}{l}\text { Random } \\
(\mathrm{n}=30)\end{array}$ & $\mathbf{P}$ & $\begin{array}{c}\text { Nest } \\
(\mathrm{n}=35)\end{array}$ & $\begin{array}{l}\text { Random } \\
(n=60)\end{array}$ & $\mathbf{P}$ & $\begin{array}{c}\text { Nest } \\
(n=58)\end{array}$ & $\begin{array}{l}\text { Random } \\
(\mathrm{n}=30)\end{array}$ & $\mathbf{P}$ \\
\hline Shrub cover (\%) & $51(6)$ & $6(1)$ & $<0.01$ & $59(4)$ & $7(2)$ & $<0.01$ & $20(2)$ & $7(1)$ & $<0.01$ & $18(2)$ & $7(2)$ & $<0.01$ \\
\hline Shrub height (cm) & $59(7)$ & $15(2)$ & $<0.01$ & $63(4)$ & $13(3)$ & $<0.01$ & $25(3)$ & $9(1)$ & $<0.01$ & $22(2)$ & $10(2)$ & $<0.01$ \\
\hline \multicolumn{13}{|l|}{ Grass cover $(\%)$} \\
\hline Short, $<18 \mathrm{~cm}$ & $8(3)$ & $22(3)$ & $<0.01$ & $17(2)$ & $24(3)$ & 0.02 & $13(2)$ & $19(1)$ & $<0.01$ & $20(1)$ & $22(2)$ & 0.31 \\
\hline Tall, $>18 \mathrm{~cm}$ & $26(5)$ & $18(2)$ & 0.13 & $27(4)$ & $17(3)$ & 0.07 & $16(2)$ & $18(2)$ & 0.52 & $15(2)$ & $11(2)$ & 0.2 \\
\hline Forb cover $(\%)$ & $12(3)$ & $12(2)$ & 0.95 & $21(3)$ & $16(2)$ & 0.18 & $10(2)$ & $9(1)$ & 0.54 & $20(2)$ & $13(1)$ & 0.23 \\
\hline Residual cover $(\%)$ & $8(3)$ & 2(1) & 0.02 & $4(1)$ & $1(1)$ & 0.23 & $2(1)$ & $2(0.4)$ & 0.42 & $3(1)$ & $1(0.3)$ & 0.15 \\
\hline Residual cover height $(\mathrm{cm})$ & $7(3)$ & $3(1)$ & 0.15 & $7(2)$ & $6(3)$ & 0.88 & $2(1)$ & $1(0.2)$ & 0.35 & $2(1)$ & $2(0.5)$ & 0.93 \\
\hline Vertical cover height $(\mathrm{cm})$ & $44(4)$ & $6(1)$ & $<0.01$ & $32(2)$ & $7(1)$ & $<0.01$ & & & & & & \\
\hline Bare ground (\%) & $25(5)$ & $57(3)$ & $<0.01$ & $15(2)$ & $52(4)$ & $<0.01$ & $42(3)$ & $44(2)$ & 0.55 & $36(2)$ & $45(3)$ & 0.01 \\
\hline Litter $(\%)$ & $57(6)$ & $24(2)$ & $<0.01$ & $79(2)$ & $30(4)$ & $<0.01$ & $32(3)$ & $26(2)$ & 0.04 & $9(2)$ & $34(3)$ & $<0.01$ \\
\hline
\end{tabular}


Table 2. Mean (SE) habitat characteristics of successful and depredated sage grouse nest sites and nest areas on the Yakima Training Center, Yakima and Kittitas counties, Washington, 1992-93.

\begin{tabular}{|c|c|c|c|c|c|c|c|c|}
\hline \multirow{2}{*}{ Variable } & \multicolumn{4}{|c|}{ Nest Sites } & \multicolumn{4}{|c|}{ Nest Areas } \\
\hline & \multicolumn{2}{|c|}{1992} & \multicolumn{2}{|r|}{1993} & \multicolumn{2}{|r|}{1992} & \multicolumn{2}{|r|}{1993} \\
\hline Shrub height $(\mathrm{cm})$ & $57(11) \mathrm{A}$ & $56(9) \mathrm{A}$ & $63(6) A$ & $64(7) A$ & $27(6) A$ & $21(4) A$ & $23(3) A$ & $21(3) \mathrm{A}$ \\
\hline \multicolumn{9}{|l|}{ Grass cover $(\%)$} \\
\hline Short, $<18 \mathrm{~cm}$ & $8(4) A$ & $7(3) \mathrm{A}$ & $14(3) \mathrm{A}$ & 21(4)A & $9(3) \mathrm{A}$ & $16(3) \mathrm{B}$ & $18(2) \mathrm{A}$ & $22(2) \mathrm{A}$ \\
\hline Residual cover (\%) & $19(10) A$ & $5(3) B$ & $5(3) \mathrm{A}$ & $3(1) A$ & $7(4) \mathrm{A}$ & $1(0.3) \mathrm{B}$ & $3(1) A$ & $2(1) A$ \\
\hline Residual cover height $(\mathrm{cm})$ & $15(7) \mathrm{A}$ & $4(3) B$ & $7(3) \mathrm{A}$ & $6(2) A$ & $6(4) \mathrm{A}$ & $1(0.3) \mathrm{B}$ & 2(1)A & $3(1) \mathrm{A}$ \\
\hline Vertical cover height $(\mathrm{cm})$ & $44(7) A$ & $42(6) \mathrm{A}$ & $36(3) \mathrm{A}$ & $30(3) \mathrm{A}$ & & & & \\
\hline Bare ground $(\%)$ & $22(10) A$ & 28(6)A & $18(3) \mathrm{A}$ & $13(2) \mathrm{A}$ & $44(5) \mathrm{A}$ & $43(4) \mathrm{A}$ & $35(3) \mathrm{A}$ & $35(3) \mathrm{A}$ \\
\hline Litter $(\%)$ & $55(11) A$ & 53(7)A & $73(4) \mathrm{A}$ & $83(3) \mathrm{B}$ & $31(5) \mathrm{A}$ & $31(4) \mathrm{A}$ & $51(3) \mathrm{A}$ & $48(3) \mathrm{A}$ \\
\hline
\end{tabular}

${ }^{a}$ Means within row, year, and location (site or area) with different letters are significantly different (P $\left.\leq 0.10\right)$ by ANOVA.

nest areas in 1992 had less short grass cover than depredated areas. Residual cover was greater at successful nest sites than at depredated nest sites in 1992. In 1993, tall grass cover at successful nest areas was greater than at depredated nest areas $(\mathrm{P}<0.1)$.

\section{Discussion and Conclusions}

Nesting success estimates from sage grouse radio-telemetry studies range from $10 \%$ in Oregon (Gregg 1992) to $70 \%$ in Montana (Wallestad 1975). Sage grouse nest success compiled from 12 studies with 699 nests was 35\% (Bergerud 1988). In comparison, hased on 2 years of data, sage grouse on the Yakima Training Center (YTC) had moderate to high nesting success.

Overall, $71 \%$ (66 of 93) of nests on the YTC were in big sagebrush/bunchgrass. Nesting sage grouse in Oregon selected cover types with greater medium $(40-80 \mathrm{~cm})$ shrub cover than cover types used less than their availability (Gregg 1992). In Idaho, sage grouse selected nest sites in sagebrush stands with tall grasses (Wakkinen 1990). Sage grouse during this study may have used big sagebrush/bunchgrass for nesting because it was abundant and because both overhead (sagebrush) and horizontal cover (herbaceous vegetation) occurred there.

Each year, most hens on the YTC nested under sagebrush. Sagebrush nesting cover was important to sage grouse in Idaho, where nest success under sagebrush was greater than under nonsagebrush vegetation (Connelly et al. 1991). During both years, we found no differences between success rates for nests under sagebrush compared with nonsagebrush nests. Abundant alternate cover (especially tall grass and residual herbaceous cover) on the YTC possibly provided ample nest concealment in both sagebrush and nonsagebrush overstories.

Sage grouse on the YTC selected nest sites and nest areas with greater shrub cover, shrub height, and less short grass cover than random locations. Sage gruuse also selected sites with greater vertical height each year, greater residual cover in 1992, and greater tall grass in 1993 than available at random sites. We could not compare vegetation measurements between nest sites and nest areas because plot sizes differed, but shrub cover and height appeared greater at nest sites than nest areas. Other studies reported greater mean shrub heights at sage grouse nests compared with surrounding vegetation (Wakkinen 1990, Musil et al. 1994).
Hulet et al. (1986) in Idaho found greater shrub cover and height at nest sites than nest areas and noted $7 \%$ of nests under Russian thistle (a major component of residual cover on the YTC). Nest sites in Oregon had greater vertical cover height than random locations (Gregg 1992), and Klebenow (1969) found greater grass cover at nests than at random sites in Idaho. Short grass may not provide enough nest concealment, which may explain why so little of this cover was found at nest sites and areas each year.

Sage grouse on the YTC apparently selected nest locations based on vegetative characteristics at both the nest-area and the nest-site levels. We found consistent vegetative differences between nest vs random sites, and nest vs random areas and apparent differences between nest sites vs nest areas. Similar results in Oregon led Gregg (1992) to conclude that sage grouse selected nest locations based on a small area $\left(3 \mathrm{~m}^{2}\right)$. We suggest that hens on the YTC may first have selected nest areas of above average cover and, within those areas, nested at sites of even greater cover.

Successful nest areas in the big sagebrush/bunchgrass cover type had greater tall grass cover than depredated nest areas each year. Tall grass cover and medium height $(40-80 \mathrm{~cm})$ shrub cover were 2 factors that distinguished successful from depredated sage grouse nests in Oregon (Gregg et al. 1994). The abundance of tall grass on the YTC may have been related to frequent fire and low livestock stocking rates.

During this study most hens nested under big sagebrush within the big sagebrush/bunchgrass cover type. Management that protects both the shrub and herbaceous components of the big sagebrush/bunchgrass community is essential for maintaining nesting habitat for sage grouse on the YTC. Disturbance (i.e., fires, road construction, grazing, trampling or uprooting caused by military training, herbicide spraying) that damages shrubs, reduces herbaceous cover, and allows exotic plants (e.g., cheatgrass and knapweed), to invade will negatively impact sage grouse nesting habitat on the YTC. Although sage grouse used Russian thistle for nesting in this study, we believe that restoring native sagebrush communities would provide better habitat. Within the big sagebrush cover type, maintaining a balance between shrub and herbaceous understory cover should be a management objective. Sagebrush communities with abundant herbaceous cover appear to have the highest probability of concealing sage grouse nests. Increasing native perennial bunchgrasses and forbs would enhance both cover and food in sagebrush cover types. 


\section{Literature Cited}

Bergerud, A.T. 1988. Population ecology of North American grouse. pp. 578-685 In: A.T. Bergerud and M.W. Gratson, eds. Adaptive strategies and population ecology of northern grouse. Univ. Minnesota Press, Minneapolis, Minn.

Canfield, R. 1941. Application of the line interception method in sampling of range vegctation. J. For. 39:386-394.

Connelly, J.W., W.L. Wakkinen, A.D. Apa, and K.P. Reese. 1991. Sage grouse use of nest sites in southeastern Idaho. J. Wildl. Manage. 55:521-524.

Daubenmire, R.F. 1959. A canopy-coverage method of vegetation analysis. Northwest Sci. 33:224-227.

Delong, A.K., J.A. Crawford, and D.C. Delong. 1995. Relationships between vegetational structure and predation of artificial sage grouse nests. J. Wildl. Manage. 59:88-92.

Giesen, K.M., T.J. Schoenberg, and C.E. Braun. 1982. Methods for trapping sage grouse in Colorado. Wildl. Soc. Bull. 10:224-231.

Gregg, M.A. 1992. Use and selection of nesting habitat by sage grouse in Oregon. M.S. Thesis, Oregon State Univ., Corvallis, Ore. 46 pp.

Gregg, M.A., J.A. Crawford, M.S. Drut, and A.K. Delong. 1994. Vegetational cover and predation of sage grouse nests in Oregon. J. Wildl. Manage. 58:162-166.

Hitchcock, C.L., and A. Cronquist. 1987. Flora of the Pacific Northwest. Sixth ed. Univ. Washington Press, Seattle, Wash. 730 pp.

Hofmann, L.A. 1991. The western sage grouse (Centrocercus urophasianus phaios) on the Yakima Training Center in central Washington. M.S. Thesis, Central Washington Univ., Ellensburg, Wash. 177 pp.

Hulet, B.V., J.T. Flinders, J.S. Green, and R.B. Murray. 1986. Seasonal movements and habitat selection of sage grouse in southern Idaho. pp 168-175 In: E.D. McArthur and B.L. Welch, compilers. Proc. of a symposium on the biology of Artemesia and Chrysothannus. U.S. For. Serv. Gen. Tech. Rep. INT-200.
Johnson, D.H. 1980. The comparison of usage and availability measurements for evaluating resource preference. Ecol. 61:65 -71.

Klebenow, D.A. 1969. Sage grouse nesting and brood habitat in Idaho. J. Wildl. Manage. 33:649-662.

Musil, D., K.P. Reese, and J.W. Connelly. 1994. Nesting and summer habitat use by translocated sage grouse (Centrocercus urophasianus) in central Idaho. Great Basin Nat. 54:228-233.

Neu, C.W., C.R. Byers, and J.M. Peek. 1974. A technique for analysis of utilization-availability data. J. Wildl. Manage. 38:541-545.

Odum, E.P., and E.J. Kuenzler. 1955. Measurement of territory and home range size in birds. Auk 72:128-137.

Robel, R.J., J.N. Briggs, A.D. Dayton, and L.C. Hulbert. 1970. Relationship between visual obstruction measurements and weight of grassland vegetation. J. Range Managc. 23:295-297.

SAS Institute Inc. 1989. SAS/STAT user's guide. Version 6. Vol. 2. Fourth ed. SAS Inst. Inc., Cary, N.C. 795 pp.

Scbroeder, M.A., and C.E. Braun. 1991. Walk-in traps for capturing greater prairie chickens on leks. J. Field Ornithol. 62:378-385.

Wakkinen, W.L. 1990. Nest site characteristics and spring-summer movements of migratory sage grouse in southeastern Idaho. M.S. Thesis, Univ. Idaho, Moscow. $57 \mathrm{pp}$

Wallestad, R.O. 1975. Life history and habitat requirements of sage grouse in central Montana. Mont. Dept. Fish and Game, Helena, Mont. 65 pp.

Wallestad, R.O., and D.B. Pyrah. 1974. Movement and nesting of sage grouse hens in central Montana. J. Wildl. Manage. 38:630-633.

Washington Department of Fish and Wildlife. 1995. Washington state management plan for sage grouse. Game Div., Wash. Dept. Fish and Wildl., Olympia, Wash. 101 pp.

Zar, J.H. 1984. Biostatistical analysis. Second ed. Prentice-Hall, Inc. Englewood Cliffs, N.J. 718 pp. 